\title{
A STUDY ON EPIPHYTIC LICHENS FROM PRUNUS PERSICA
}

\author{
RAMYA K, THIRUNALASUNDARI T* \\ Department of Industrial Biotechnology, Bharathidasan University, Tiruchirappalli - 620 024, Tamil Nadu, India. \\ Email: drttns@gmail.com/drttns@bdu.ac.in
}

Received: 13 October 2017, Revised and Accepted: 28 November 2017

\section{ABSTRACT}

Objective: The objective of this study is to explore and identify the epiphytic lichens on the tree bark of Prunus persica from Kodaikanal area and analyze its phytochemical properties.

Methods: Samples were collected from Kodaikanal area, identified by morphological and chemical constituents. Macromolecules present were quantified by DNS method, Lowry's method, and lipid tests. The secondary metabolites present were analyzed by standard phytochemical tests and thin-layer chromatography.

Results and Conclusion: It was interesting to observe that species belonging to the lichen genera - Parmotrema, Ramalina, and Usnea dominated the area. The samples have been identified and deposited in LWG herbarium, NBRI, Lucknow. As lichens form an ideal model to study the humongous secondary metabolites present in it, a preliminary investigation was performed to understand the nutritive value as well as phytochemicals present in the lichens. The results indicate that these organisms can be of potential medicinal value with Ramalina and Usnea species contributing good amount of macronutrients present in them, while qualitative analysis of phytochemicals reports all the lichens for enormous metabolites.

Keywords: Epiphytic lichens, Kodaikanal, Thin-layer chromatography, Phytochemistry, Prunus persica.

(c) 2018 The Authors. Published by Innovare Academic Sciences Pvt Ltd. This is an open access article under the CC BY license (http://creativecommons. org/licenses/by/4. 0/) DOI: http://dx.doi.org/10.22159/ajpcr.2018.v11i3.23066

\section{INTRODUCTION}

As a worldwide spread consortium of self-supporting associations, lichens represent a symbiotic association between the photobiont (algae) and the mycobiont (fungi). Lichens grow anywhere and on anything covering approximately $8 \%$ of Earth's surface [1]. These lichens are slow-growing organisms that occupy harsh environments of life. This property of lichen marks it as a pollution indicating organisms and the best biomonitors of air quality [2]. Lichens carry thousands of secondary chemicals in them, and over the past two decades, there has been a growing interest in lichens as a source of novel and pharmacologically active biomolecules [3]. The use of lichens as folk medicine has been reported across the world since centuries, particularly in temperate and arctic regions due to its nutritive value and impressive medicinal properties [4]

Moderate temperature, sufficient sunlight, and moisture are the necessary conditions for growth of lichens, making it adaptable to survive varying climates and altitudes around the world. These species are found on rocks, soil, trees, and land surfaces. Epiphytic lichens are the lichens which grow on the tree surfaces, more often on healthy trees as well as in stressed and unhealthy trees. The physical parameters of the tree are very critical for the type of lichen growing on it; smoother surface of the bark allows a crustose form of lichens to grow while uneven surfaces facilitate attachment of foliose and fruticose type of lichens.

Before the $19^{\text {th }}$ century, the lichens were grouped based only on the morphological parameters. With the advent of advanced microscopic techniques like electron microscope, it became possible for minute observation of the morphological structures of the species that led to a proper taxonomical identification. However, the important feature toward identifying lichens is based on its chemistry, which is widely used as a taxonomic tool for over a century [5]

While Lichen diversity shares $2.4 \%$ of global land surface, India shares the richness of lichen diversity contributing to nearly $15 \%$ among the species of lichens recorded by lichenologists worldwide [6,7]. However, there are many more untouched regions in India, especially mountains and forest canopies among the Eastern and Western Ghats that needs to be explored. Kodaikanal, which is located in the Palani hills, have a diversity of lichens with medicinal and ecosystem values that can be noticed throughout the area. In Tamil Nadu, a total of about 555 lichen species under 128 genera have been reported [8]. However, a majority of lichens reported in the study have not been included in the checklist which is very well indicative that the lichens of Kodaikanal have not been explored completely for its biodiversity.

To understand the diversity of lichens present, this has been a preliminary work in randomly collecting a few of the epiphytic lichens from the tree Prunus persica at Kodaikanal area which has been deposited in LWG herbarium, NBRI, Lucknow.

\section{MATERIALS AND METHODS}

Collection of the study material

All the lichen samples chosen for the study were collected manually from the peach tree, P. persica.

\section{Identification of lichen species}

The lichens collected were identified at NBRI, Lucknow, with the help of Dr. Sanjeeva Nayaka, Principal Scientist, Lichenology laboratory. The lichens were identified by studying the morphological, microscopical, and chemical characteristics [9].

\section{Observation and categorization}

The general characteristics of the fruiting bodies were observed under the compound microscope at a magnification of $\times 40$. The color of the thallus, texture, presence of isidia, soredia, pruina, and pycnidia on the upper surface were observed. The presence of pores and rhizines as well as the color on the lower surface was also noted. Characteristic structures such as apothecia and perithecia were looked on the thallus. The presence of ascospores was observed by taking a thin hand section 
of the thallus or the ascocarp. Further, the lichens were grouped based on the growth form, crustose, squamulose, foliose, and fruticose type.

\section{Chemistry of lichens}

To understand the nutritive value of lichens, the primary metabolites were analyzed. Reducing sugars present were estimated by DNS method [10], protein by Lowry's method [11], and lipids using cholesterol kit supplied by M/S Biosystems.

Phytochemical analyses were carried out for the acetone extracts of the lichen samples following standard protocols $[12,13]$. The preliminary identification of the chemical compounds present in lichens were analyzed by spot tests - K test, C test, KC test, and PD test [14,15]. Thinlayer chromatography (TLC) was performed to further confirm the lichen chemistry using acetone extracts of the lichens $[9,16]$.

\section{RESULTS}

The samples sharing different niches of the tree, P. persica, was collected manually from Kodaikanal, shade dried, and segregated for identification. Macroscopic and microscopic features of the lichens were observed for the initial characterization at NBRI, Lucknow (Fig. 1 and Table 1). Based on the attachment of the thallus to the substratum, the lichens are categorized into different types: Crustose lichens - which attach tightly against the substrate, squamulose lichens - which are tightly clustered and slightly flattened pebble- like units, foliose lichens - leaf like which are not tightly bound, and fruticose lichens - which are free-standing branching tubes. The lichen species identified in the present study are epiphytic lichens which represent all the lichen categories. Ramalina conduplicans (Fig. 1a), Ramalina subpusilla (Fig. 1b), Ramalina sinensis (Fig. 1k), Usnea cineraria (Fig. 1h), and Usnea sp., (Fig. 1i) are fruticose type of lichens. Parmotrema reticulatum (Fig. 1c), Parmotrema cristiferum (Fig. 1d), and Canoparmelia texana (Fig. 10) belong to foliose type of lichens. Lecanora caesiorubella (Fig. 1e), Lecanora cenisia (Fig. 1f), and Lecanora helva (Fig. 1n) represent crustose forms of lichens, while Chrysothrix chlorina (Fig. 11), Hafellia curatellae (Fig. 1j), and Phaeographis intricans (Fig. $1 \mathrm{~m}$ ) belong to the squamulose type. It was observed that foliose and fruticose lichens were abundantly present all over the tree trunk and branches of $P$. persica while there were only few squamulose lichens. All the respective voucher specimens that were identified have been deposited with its respective accession numbers in LWG virtual herbarium, Lucknow (Table 2).

Considerable amount of the macromolecules were present in lichens (Table 3). R. conduplicans is reported to have the highest content of reducing sugar $(900 \mu \mathrm{g} / \mathrm{g}$ of sample), protein (930 $\mathrm{gg} / \mathrm{g}$ of sample), and lipid (26.07 $\mu \mathrm{g} / \mathrm{g}$ of sample) (Table 3). Parmotrema species also showed a considerable amount of macromolecules with similar content of glucose, protein, and lipid. $R$. subpusilla showed a higher amount of protein content, while $U$. cineraria revealed higher lipid content.

Table 1: Categorization of lichens based on growth form, morphology, and microscopy

\begin{tabular}{|c|c|c|c|}
\hline Sl. No. & Code No. & Growth form & Morphological and microscopical characteristics \\
\hline 1 & KP001 & Fruticose & $\begin{array}{l}\text { Thallus shrubby, corticolous, forked branches ending with nodular structures, surface flat, pseudophyllae } \\
\text { abundant on lower surface of the branches. Has dorsiventral main lobes with thin secondary branches } \\
\text { that are tapering toward the apices. Grayish-green in color. Apothecia present. Ascospores are long and } \\
\text { wide in size }\end{array}$ \\
\hline 2 & KP001A & Fruticose & $\begin{array}{l}\text { Thallus fragile, lobe cavity is open and tube-like. Grayish-green in color, smooth, and striately ridged. } \\
\text { Apothecia present. } 8 \text { bicelled ascospores seen }\end{array}$ \\
\hline 3 & КР002 & Foliose & $\begin{array}{l}\text { Thallus loosely held to the substratum which is } 5-16 \mathrm{~cm} \text { in diameter. The lobes were elongate, irregular, } \\
\text { and plane with round margin. Cilia at the margin of the thallus observed. Upper surface was pale gray, } \\
\text { dull, and smooth. Soredia found in the margins. Lower surface is black with rhizines }\end{array}$ \\
\hline 4 & КР003 & Foliose & $\begin{array}{l}\text { Thallus loosely held to the substratum, } 3-15 \mathrm{~cm} \text { in diameter. Lobes were subirregular, elongate. Had } \\
\text { round apices with cilia around it. The upper surface is gray, smooth, dull. Soredia is granular. Lower } \\
\text { surface is black and brown with rhizines }\end{array}$ \\
\hline 5 & KP004 & Crustose & $\begin{array}{l}\text { Thallus is areolate and dispersed throughout the substratum. Surface is whitish gray, smooth, epruinose } \\
\text { with no distinct margin. Apothecia is sessile. Amphithecium and parathecium present with crystal-like } \\
\text { structures. Simple ascospores observed. Pyncidia not seen }\end{array}$ \\
\hline 6 & КР005 & Crustose & $\begin{array}{l}\text { Thallus is areolate and dispersed throughout the substratum. Surface is yellowish-gray with a distinct } \\
\text { margin. Apothecia is sessile. Amphithecium and parathecium present with large crystalline structures. } \\
\text { Ellipsoid ascospores observed. Pyncidia not seen }\end{array}$ \\
\hline 7 & КP006 & Fruticose & $\begin{array}{l}\text { Thallus shrubby, corticolous, forked branches ending with nodular structures, surface flat, pseudophyllae } \\
\text { abundant on lower surface of the branches. Has dorsiventral main lobes with thin secondary branches } \\
\text { that are tapering toward the apices. Grayish-green in color. Apothecia present. Ascospores are long and } \\
\text { wide in size }\end{array}$ \\
\hline 8 & КР007 & Fruticose & $\begin{array}{l}\text { Thallus is erect and branching. Surface is dark brown with black-colored basal disc. The lateral branches } \\
\text { are divergent that are dense toward apical region and perpendicular, simple to branched position. The } \\
\text { surface is slightly shiny and densely papillated. Cilia found throughout the margins }\end{array}$ \\
\hline 9 & КР008 & Fruticose & $\begin{array}{l}\text { Thallus is tufted. Surface is grayish-green blackened base that is attached to substratum. Secondary } \\
\text { branches are crowded and densely covered with minute ciliated structures }\end{array}$ \\
\hline 10 & КР009 & Fruticose & $\begin{array}{l}\text { Thallus is corticolous, erect, broad, flat, and reticulate. Upper surface is green and lower surface is } \\
\text { whitish. Apothecia is numerous with ascospores }\end{array}$ \\
\hline 11 & КР010 & Squamulose & $\begin{array}{l}\text { Thallus is granular and cracked in between, areolate. Surface of the entire thallus is powdery and } \\
\text { yellowish }\end{array}$ \\
\hline 12 & KP010A & Squamulose & $\begin{array}{l}\text { Thallus is corticolous. Surface is grayish-white to pale yellow-brown with black disc-shaped structures. } \\
\text { Apothecia is covex in shape with thick black margin }\end{array}$ \\
\hline 13 & КР010B & Squamulose & $\begin{array}{l}\text { Thallus is pale, thin, smooth, and whitish. Presence of fine white pruinose Apothecia are slit-like } \\
\text { lirellae and immersed within the thallus. Ascocarps are densely stellate and the branches adjoining are } \\
\text { separated by very narrow non- thalloid tissue }\end{array}$ \\
\hline 14 & KP010C & Crustose & $\begin{array}{l}\text { Thallus is continuous with blackish areoles. Surface is yellowish white, smooth, epruinose present with } \\
\text { indistinct margin. Soredia is granular. Apothecia is seen subimmersed along the thallus }\end{array}$ \\
\hline 15 & КР011 & Foliose & $\begin{array}{l}\text { Thallus has irregular and elongated lobes. Upper surface is pale greenish-gray and lower surface is } \\
\text { brownish-black }\end{array}$ \\
\hline
\end{tabular}




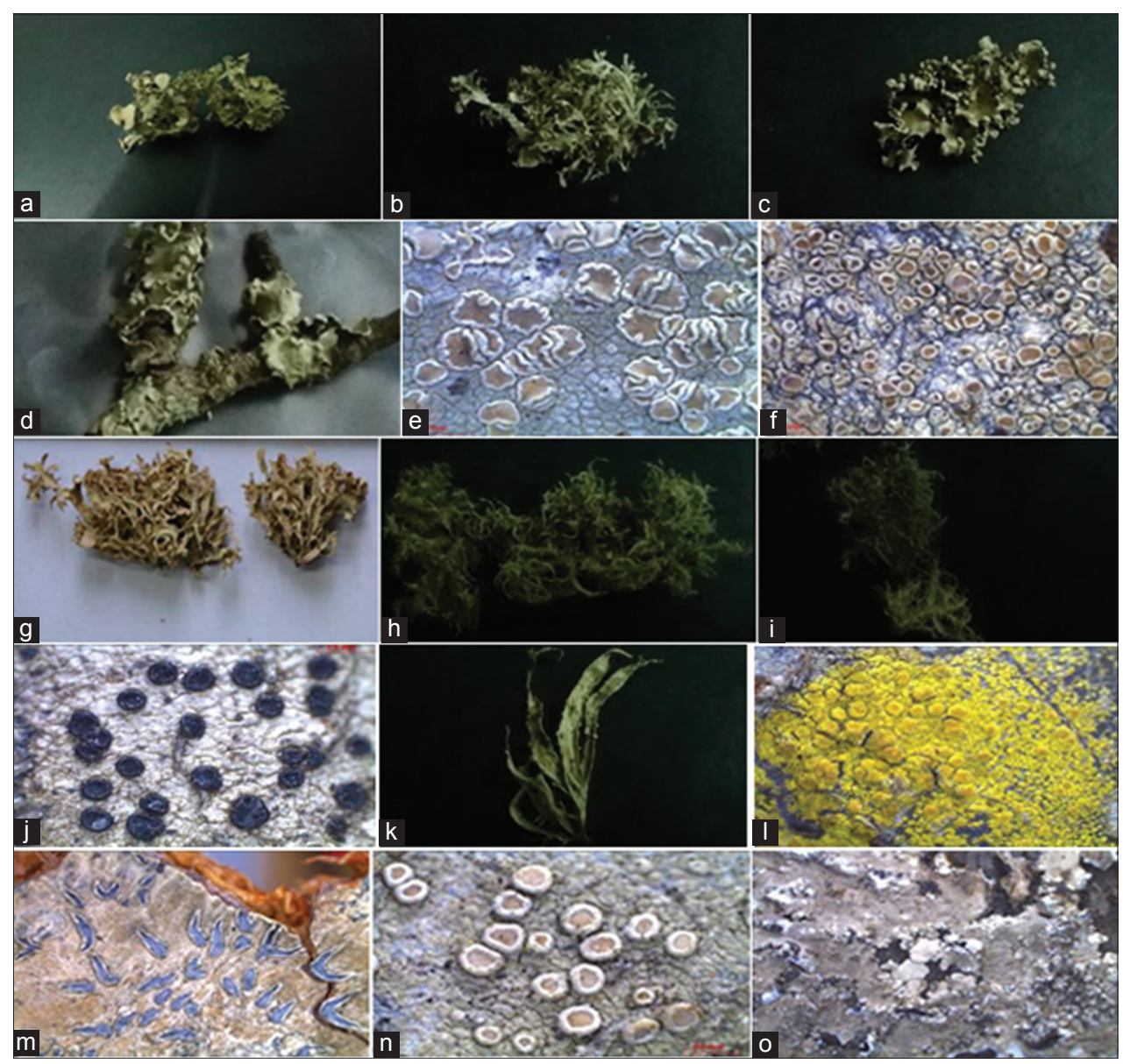

Figure 1: Identified lichens. (a) Ramalina conduplicans Vain. (b) Ramalina subpusilla (Nyl.) Krog and Swinsc. (c) Parmotrema reticulatum (Taylor) Choisy. (d) Parmotrema cristiferum (Taylor) Hale, (e) Lecanora caesiorubella Ach. (f) Lecanora cenisia Ach. (g) R. conduplicans Vain. (h) Usnea cineraria Mot. (i) Usnea sp. (j) Hafellia curatellae (Malme) Marbach. (k) Ramalina sinensis Jatta, (l) Chrysothrix chlorina (Ach.) J.R. Laundon. (m) Phaeographis intricans (Nyl.) Vain. (n) Lecanora helva Stizenb. (o) Canoparmelia texana (Tuck.) Elix and Hale

Table 2: List of lichens identified and deposited at LWG herbarium, NBRI, Lucknow

\begin{tabular}{|c|c|c|}
\hline Code No. & Species & $\begin{array}{l}\text { Accession no. } \\
\text { of LWG }\end{array}$ \\
\hline 1 - КР001 & Ramalina conduplicans Vain. & 35125 \\
\hline 1 - КР001A & $\begin{array}{l}\text { Ramalina subpusilla (Nyl.) Krog and } \\
\text { Swinsc. }\end{array}$ & 35126 \\
\hline 2 - КР002 & $\begin{array}{l}\text { Parmotrema reticulatum (Taylor) } \\
\text { Choisy }\end{array}$ & 35136 \\
\hline 3 - КР003 & $\begin{array}{l}\text { Parmotrema cristiferum (Taylor) } \\
\text { Hale }\end{array}$ & 35128 \\
\hline 4 - КР004 & Lecanora caesiorubella Ach. & 35130 \\
\hline 5 - КР005 & Lecanora cenisia Ach. & 35127 \\
\hline 6 - КР006 & Ramalina conduplicans Vain. & 35131 \\
\hline 7 - КР007 & Usnea cineraria Mot. & 35133 \\
\hline 8 - КР008 & Usnea sp. & 35132 \\
\hline 9 - КР009 & Ramalina sinensis Jatta & 35129 \\
\hline 10 - КР010 & $\begin{array}{l}\text { Chrysothrix chlorina (Ach.) J.R. } \\
\text { Laundon, Hafellia curatellae (Malme) } \\
\text { Marbach, Phaeographis } \\
\text { intricans (Nyl.) Vain., Lecanora helva } \\
\text { Stizenb. }\end{array}$ & 35135 \\
\hline 11 - КР011 & $\begin{array}{l}\text { Canoparmelia texana (Tuck.) Elix and } \\
\text { Hale }\end{array}$ & 35134 \\
\hline
\end{tabular}

Preliminary analysis to understand the category of phytochemicals in lichens portrayed the presence of phenols, tannins, flavonoids, alkaloids, steroids, terpenes, glycosides, and saponins (Table 4).
Apart from alkaloids and saponins, all the metabolites were present in $R$. subpusilla, while in $R$. conduplicans, steroids and saponins were not observed. Both the Parmotrema species indicated the presence of all the metabolites, while only saponins were absent. Lecanora species did not show the presence of terpenoids, glycosides, and saponins. In Usnea species, alkaloids and terpenoids were not found while other metabolites were prominent for the test.

Depsides and depsidones were the major compounds detected in most of the lichen tested followed by the presence of atranorin in spot analysis (Table 5). Presence of usnic acid was seen in all the species of Ramalina, Parmotema, and Usnea lichens. Lecanora cenisia indicated the presence of didymic acid and pannaric acid. Pulvinic acid derivatives were the result of spot test in C. chlorina.

TLC analysis of the acetone extracts of the lichens gave a picture about the presence of several compounds in lichens with reference to standards (Fig. 2 and Table 6). It was observed that majority of the lichens have atranorin and salazinic acids. $R$. conduplicans was identical with the presence of sekikaic acid. Usnea sp. reported the presence of stictic and norstictic acid along its characteristic usnic acid. It was interesting to note that no distinctive chromatogram developed for $R$. sinensis and $H$. curatellae. L. cinesia had only atranorin while $L$. caesiorubella also reported protocetraric acid. Divaricatic acid complex along with atranorin was found in C. texana.

\section{DISCUSSION}

Epiphytic lichens are known as environmental indicators. The lichen categories, particularly, the foliose and fruticose are 
characteristic forms of epiphytic lichens. In this study, important lichen species were identified such as the Ramalina, Parmotrema, and Usnea species. It was noted that the lichen hyphae penetrated the bark of the tree, P. persica causing damaging effect on the

Table 3: Quantity of macromolecules present in lichen samples

\begin{tabular}{lllll}
\hline S. No. & $\begin{array}{l}\text { Lichen } \\
\text { code no }\end{array}$ & $\begin{array}{l}\text { Reducing } \\
\text { sugar } \boldsymbol{\mu g} / \mathrm{g} \text { of } \\
\text { the sample }\end{array}$ & $\begin{array}{l}\text { Proteins } \boldsymbol{\mu g} / \mathrm{g} \\
\text { of the sample }\end{array}$ & $\begin{array}{l}\text { Lipid } \boldsymbol{\mu g} / \mathrm{g} \\
\text { of sample }\end{array}$ \\
\hline 1 & KP001A & 690 & 850 & 15.14 \\
2 & KP002 & 720 & 150 & 22.10 \\
3 & KP003 & 720 & 150 & 22.10 \\
4 & KP004 & 240 & 280 & 13.11 \\
5 & KP005 & 210 & 165 & 16.0 \\
6 & KP006 & 900 & 930 & 26.07 \\
7 & KP007 & 300 & 260 & 18.76 \\
\hline
\end{tabular}

tree. Hale [17] also reported that the lichen rhizines penetrate extensively throughout the cortex, bast, and the cambium of living wood. Lichens coexistence with plants is reported for a long time, and hence, it is understood that plants have developed various defense mechanism against the penetration of lichens. Hence, apart from its deleterious effects, healthy trees with numerous epiphytic lichens can also be seen [18].

Traditional preparative methods such as boiling and steaming are used to make the macrolichens edible. This removes the lichen secondary compounds and hydrolyzes the lichen polysaccharides to yield glucose and other digestible simple sugars [19]. Macromolecular analysis of the lichens in this report specifies the presence of considerable quantity of carbohydrates, proteins, and lipids in the samples analyzed. $R$. conduplicans is reported to have a high content of the macromolecules (Table 3). This is evident with the fact that the lichen $R$. conduplicans is an edible lichen that has been used for cooking

Table 4: Secondary metabolites found in lichen samples

\begin{tabular}{|c|c|c|c|c|c|c|c|c|c|}
\hline S. No. & Code No. & Phenols & Tannins & Flavonoids & Alkaloids & Steroids & Terpenoids & Glycosides & Saponins \\
\hline 01 & KP001A & + & + & + & - & + & + & + & - \\
\hline 02 & KP002 & + & + & + & + & + & + & + & - \\
\hline 03 & КР003 & + & + & + & + & + & + & + & - \\
\hline 04 & КР004 & + & + & + & + & + & - & - & - \\
\hline 05 & KP005 & + & + & + & + & + & - & - & - \\
\hline 06 & КР006 & + & + & + & + & - & + & + & - \\
\hline 07 & КР007 & + & + & + & - & + & - & + & + \\
\hline
\end{tabular}

+Indicates presence of the metabolite, -Indicates absence of the metabolite

Table 5: Lichen phytochemicals - spot analysis

\begin{tabular}{|c|c|c|c|c|c|c|c|}
\hline \multirow[t]{2}{*}{ S. No. } & \multirow[t]{2}{*}{ Code No. } & \multicolumn{4}{|l|}{ Color tests } & \multirow{2}{*}{$\begin{array}{l}\text { Other test } \\
\text { chloramine } \mathrm{T}\end{array}$} & \multirow[t]{2}{*}{ Probable compound } \\
\hline & & C test & K test & $\mathrm{KC}$ test & PD test & & \\
\hline 1 & KP001A & - & - & - & - & + & Depsides, usnic acid \\
\hline 2 & KP002 & - & + & - & - & + & Depsides and depsidones, usnic acid \\
\hline 3 & KP003 & - & + & - & - & + & Depsides and depsidones \\
\hline 4 & КР004 & - & + & - & - & - & Depsides and depsidones \\
\hline 5 & KP005 & + & - & - & + & - & Didymic acid, pannaric acid \\
\hline 6 & KP006 & + & - & - & + & + & $\begin{array}{l}\text { Depsides - atranorin, norstictic acid, salazinic } \\
\text { acid, lecanoric acid }\end{array}$ \\
\hline 7 & КР007 & - & + & - & + & + & Usnic acid, depsidones \\
\hline 8 & KP008 & - & - & - & + & + & Usnic acid \\
\hline 9 & KР009 & - & - & + & - & + & Depsides - atranorin, usnic acid \\
\hline 10 & KP010A & - & - & - & - & - & Pulvinic acid derivatives \\
\hline 11 & КР010В & TLC analysis only & & & & & \\
\hline 12 & KP010C & & & & & & \\
\hline 13 & KP010D & - & + & - & + & + & Atranorin, methylperlatolic acid \\
\hline 14 & KP011 & + & - & - & + & - & Atranorin, divaricatic acid \\
\hline
\end{tabular}

TLC: Thin-layer chromatography

Table 6: Chemistry of lichens based on TLC

\begin{tabular}{llll}
\hline S. No. & Lichen code & Species & Chemicals as per TLC plate \\
\hline 1 & C & Control - Parmelinella wallichiana (Taylor) Elix and Hale & Salazinic acid, atranorin \\
2 & KP001A & Ramalina subpusilla (Nyl.) Krog and Swinsc. & Salazinic acid \\
3 & KP002 & Parmotrema reticulatum (Taylor) Choisy & Salazinic acid, Atranorin \\
4 & KP003 & Parmotrema cristiferum (Taylor) Hale & Salazinic acid, Atranorin \\
5 & KP004 & Lecanora caesiorubella Ach. & Protocetraric acid, atranorin, triterpene \\
6 & KP005 & Lecanora cenisia Ach. & Atranorin \\
7 & KP006 & Ramalina conduplicans Vain. & Sekikaic acid \\
8 & KP007 & Usnea cineraria Mot. & Salazinic acid, atranorin \\
9 & KP008 & Usnea sp. & Norstictic acid, stictic acid, salazinic acid, usnic acid \\
10 & KP009 & Ramalina sinensis Jatta & Not visible \\
11 & KP010A & Chrysothrix chlorina (Ach.) J.R. Laundon & Vulpinic acid \\
12 & KP010B & Hafellia curatellae (Malme) Marbach & Not visible \\
13 & KP010C & Phaeographis intricans (Nyl.) Vain. & Norstictic acid, stictic acid, constictic acid \\
14 & KP010D & Lecanora helva Stizenb. & Atranorin \\
15 & KP011 & Canoparmelia texana (Tuck.) Elix and Hale & Divaricatic acid complex, atranorin \\
\hline
\end{tabular}




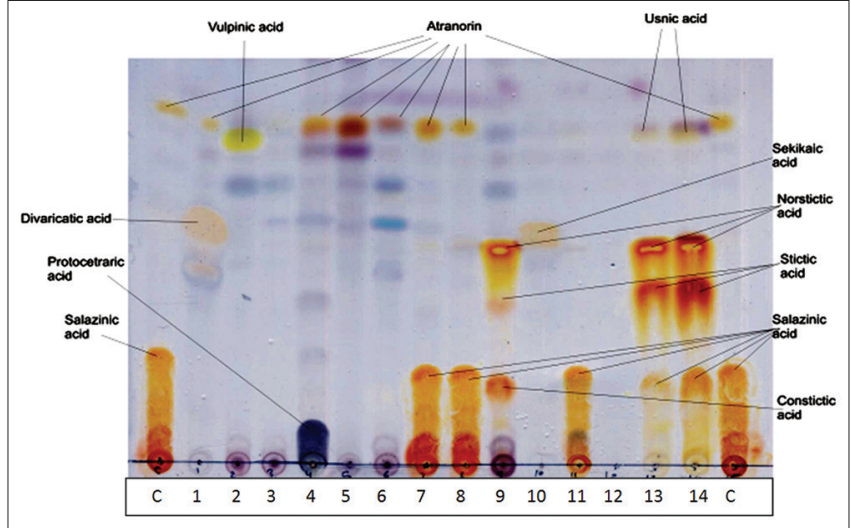

Figure 2: Compounds present in lichens based on thin-layer chromatography. (c) Control sample (Parmelinella wallichiana). (1) Ramalina subpusilla (Nyl.) Krog\&Swinsc. (2) Parmotrema reticulatum (Taylor) Choisy. (3) Parmotrema cristiferum (Taylor) Hale. (4) Lecanora caesiorubella Ach. (5) Lecanora cenisia Ach. (6) Ramalina conduplicans Vain. (7) Usnea cineraria Mot. (8) Usnea sp. (9) Ramalina sinensis Jatta. (10) Chrysothrix chlorina (Ach.) J.R. Laundon. (11) Hafellia curatellae (Malme) Marbach. (12) Phaeographis intricans (Nyl.) Vain. (13) Lecanora helva Stizenb. (14) Canoparmelia texana (Tuck.) Elix and Hale

in Central and South Eastern Asian countries [20]. High protein and reducing sugar content in $R$. conduplicans has also been reported [21]. In this study, both the Parmotrema species have portrayed good amount of macromolecules in them. Foliose parmeloid lichens are the commonly used variety as spices [22]. However, the best species reported among lichens is known to be Parmotrema perlatum, known as "black stone flower," and has been used as a common spice in India. This lichen is also reported to have important therapeutic values [23]. The tribal community is using several lichens as foods as well as they are sold in markets of Himachal Pradesh [24]. Although lichens are used in food by many different cultures across the world, there are concerns about its edibility. This is because of the indigestible nature of the lichen polysaccharides by humans. Furthermore, certain secondary metabolites such as vulpinic acid and usnic acid are reported to be toxic at higher concentration [25].

The strong presence of phenols, terpenes, tannins, and flavonoids in all the lichen samples tested supports lichen's antioxidant activity and conveys the embodiment of several important metabolites of pharmaceutical interest. Several reports have analyzed similar results, thereby grounding lichen compounds as an alternative drug source for treating diseases caused due to free radicals $[26,27]$.

Chemotaxonomic studies of several research works have indicated that lichens have the most unique secondary metabolites that represent chemical classes of depsides, depsidones, and dibenzofurans $[28,29]$. This is concomitant with the present study of the lichen species based on TLC and spot analysis. The lichen compounds analyzed have reported to have various medicinal values. Usnic acid, salazinic acid, and atranorin are the major compounds reported in this study which have several important biological roles. These compounds have strong antimicrobial property [30-32], anticancerous properties [33], antiherbivorous [34]; antioxidants [35,36], and immunomodulatory [37]. Almost all the metabolites identified in the TLC results of this study have also been reported as sources of commercial dyes [38].

\section{CONCLUSION}

This study provides evidence for a diversified category of epiphytic lichens from the same tree species, P. persica. The investigations on the lichen species with respect to its nutritive value and phytochemicals clearly merit their significant role for edibility as well as a stand for identifying potential molecules that can be of importance in the Pharma Industry.

\section{ACKNOWLEDGMENT}

The authors owe our sincere thanks to Mr. Narasimman and Dr. Anne Leukose who helped us during lichen collection at Kodaikanal. Special thanks to Dr. Sanjeeva Nayaka, Principal Scientist, Lichenology laboratory, NBRI, Lucknow, who helped us to identify the lichens in the present study.

\section{REFERENCES}

1. Ahmadjian VH. Lichens are more important than you think. Bioscience 1995;45:123-4.

2. Branquinho C, Catarino F, Brown DH, Pereira MJ, Soares A. Improving the use of lichens as biomonitors of atmospheric metal pollution. Sci Total Environ 1999;232:67-77.

3. Gulluce M, Aslan A, Sokmen M, Sahin F, Adiguzel A, Agar G, et al. Screening the antioxidant and antimicrobial properties of the lichens Parmelia saxatilis, Platismatia glauca, Ramalina pollinaria, Ramalina polymorpha and Umbilicaria nylanderiana. Phytomedicine 2006;13:515-21.

4. Shukla V, Joshi G, Rawat M. Lichens as a potential natural source of bioactive compounds: A review. Phytochem 2010;9:303-14.

5. Poelt J. Systematic evaluation of morphological characters. In: Ahmadjian V, Hale ME. The Lichens Ch. 3. New York: Academic Press; 1973.

6. Groombridge B. Global Biodiversity: Status of the Earth's Living Resources. London: Chapman and Hall; 1992.

7. Upreti DK, Negi HR. Lichen flora of Chopta Tunganath, Garhwal Himalayas, India. J Econ Tax Bot 1998;22:273-86.

8. Hariharan GN, Balaji P. Checklist of Lichens and Lichenicolous fungi of Tamil Nadu (India). Database; 1999. Available from: http://www. tnenvis.nic.in.

9. Nayaka S. Plant Taxonomy and Biosystematics: Classical and Modern Methods. Ch. 5. New Delhi: New India Publishing Agency; 2014. p. 101-28.

10. Miller GL. Use of DNS reagent for. determination of reducing sugar. Anal Chem 1972;31:426.

11. Lowry OH, Rosebrough NJ, Farr AL, Randall RJ. Protein measurement with the folin phenol reagent. J Biol Chem 1951;193:265-75.

12. Trease GE, Evans WC. Pharmacology. $11^{\text {th }}$ ed. London: Bailliere Tindall Ltd; 1989. p. 60-75.

13. Harborne JB. A guide to modern techniques of plant analysis. In: Chapman A, Hall,editors. Photochemical Methods. London: Chapman and Hall; 1973. p. 279

14. Nylander W. Circa novum in studio lichenum critericum chemicum. Flora 1866;49:198-201.

15. Asahina Y. Ueber die Reaktion von Flechten-Thallus. Acta Phytochem 1934;8:47.

16. Culberson CF. Improved conditions and new data for the identification of lichen products by a standardized thin layer chromatographic method. J Chromatogr 1972;72:113-25.

17. Hale ME. The Biology of Lichens. $3^{\text {rd }}$. ed. London: Edward Arnold; 1984.

18. Brodo IM. Substrate Ecology. In: Ahmadjian V, Hale ME. The Lichens. New York: Academic Press; 1973.

19. Lal BM, Rao KR. The food value of some Indian Lichens. J Sci Ind Res 1956;15:71-3

20. Bhattarai T, Subba D, Subba R. Nutritional value of some edible lichens of east Nepal. J Appl Bot Food Qual Angew Bot 1999;73:11-18.

21. Vinayaka KS, Kumar PS, Kekuda PT, Krishnamurthy YL, Mallikarjun N, Swathi D. Proximate composition, antioxidant, anthelmintic and insecticidal activity of a macrolichen Ramalina conduplicans Vain. (Ramalinaceae). Eur J Appl Sci 2009;1:40-6.

22. Upreti DK, Bajpai R, Nayaka S. Plant Biology and Biotechnology. Vol. 1: Plant Diversity, Organisation, Function and Improvement. New Delhi: Springer India; 2015. p. 263-80.

23. Gehlot V, Mahant S, Vijayraghwan P, Das K, Hoda S, Das R. Therapeutic potential of lichen Parmelia perlata against dual drug-resistant Helicobacter pylori isolates. Int J Pharm Pharm Sci 2016;8:205-8.

24. Upreti DK, Divakar PK, Nayaka S. Commercial and Ethnic Use of Lichens in India. Econ Bot 2005;59:269-73.

25. Emmerich R, Giez I, Lange OL, Proksch P. Toxicity and antifeedant 
activity of lichen compounds against the polyphagous herbivorous insect Spodoptera littoralis. Phytochemistry 1993;33:1389-94.

26. Mastan A, Sreedevi B, Kumari JP. Evaluation of the in-vitro antioxidant and antibacterial activities of secondary metabolites produced from lichens. Asian J Pharm Clin Res 2014;7:193-8.

27. Ghate NB, Chaudhuri D, Sarkar R, Sajem AL, Panja S, Rout J, et al. An antioxidant extract of tropical lichen, Parmotrema reticulatum, induces cell cycle arrest and apoptosis in breast carcinoma cell line MCF-7. PLoS One 2013;8:e82293.

28. Huneck S, Yoshimura I. Identification of Lichen Substances. Berlin: Springer; 1996.

29. Dem-bitsky VM, Tolstikov GA. Organic Metabolites of Lichens. Novosi-Birsk: Nauka Press; 2005. p. 135.

30. Ingólfsdóttir K. Usnic acid. Phytochemistry 2002;61:729-36.

31. Molnár K, Farkas E. Current results on biological activities of lichen secondary metabolites: A review. Z Naturforsch C 2010;65:157-73.

32. Solhaug KA, Gauslaa Y. Secondary lichen compounds as protection against excess solar radiation and herbivores. In: Lüttge $U$, Beyschlag W, Büdel B, Francis D, editors. Progress in Botany. $73^{\text {rd }}$ ed. Heidelberg: Springer; 2012. p. 283-304.
33. Bačkorová M, Jendželovský R, Kello M, Bačkor M, Mikeš J, Fedoročko $\mathrm{P}$, et al. Lichen secondary metabolites are responsible for induction of apoptosis in HT-29 and A2780 human cancer cell lines. Toxicol In Vitro 2012;26:462-8.

34. Nimis PL, Skert N. Lichen chemistry and selective grazing by the coleopteran Lasioderma serricorne. Environ Exp Bot 2006;55:175-82.

35. Behera BC, Adawadkar B, Makhija U. Tissue-culture of selected species of the graphis lichen and their biological activities. Fitoterapia 2006;77:208-15.

36. Verma N, Behera BC, Om Sharma B. Glucosidase inhibitory and radical scavenging properties of lichen metabolites salazinic acid, sekikaic acid and usnic acid. Hacettepe J Biol Chem 2012;40:7-21.

37. Thadhani VM, Mesaik MA, Asif M, Karunaratne V, Choudhary MI. Immunomodulatory activities of some common lichen metabolites. Int J Pharm Pharm Sci 2015;7:144-7.

38. Shukla P, Upreti DK. Lichen dyes: Current scenario and future prospects. In: Upreti DK, Divakar PK, Shukla V, Bajpai R, editors. Recent Advances in Lichenology: Modern Methods and Approaches in Biomonitoring and Bioprospection. New Delhi: Springer; 2015. p. 209-30. 